Владимир Јанев

\title{
СОЦИЈАЛНО-ЕКОНОМСКИТЕ АСПЕКТИ ВО ФОЛКЛОРОТ НА МАКЕДОНСКИТЕ ЕВРЕИ
}

\begin{abstract}
Апстракт: Македонските Евреи за време на османлиското владеење создавале и негувале свој автентичен фолклор. Тој се состоел од: песни, приказни, поговорки, гатанки и сл., кои биле пренесувани од поколение на поколение. Во поговорките бил опфатен односот на сите категории од еврејското население спрема трудот. Притоа се истакнувале позитивните и негативните примери, со цел етички да се влијае на младите членови на заедницата. Поговорките се употребувале многу често, во разни пригоди, било во кругот на семејството или меѓу пријатели и соседи. Народните приказни и басни, исто така, се проткаени со поговорки, кои имаат педагошка смисла. Приказните, исто како и поговорките, се производ на усното предание и ги изразувале животните проблеми на пошироката човечка заедница. Тие се полни со оптимизам и со верба во човекот и опфаќаат многу позитивни и негативни страни на секојдневниот живот. Приказните претставувале пригодна форма за спонтано изнесување на недостатоците во меѓучовечките односи, без да предизвикуваат негативни реакции. Тие обработувале семејни и општествени проблеми: односот меѓу членовите на семејството, соседите, слугата и господарот, владетелот и народот. Многу човечки особини се обработени во различни варијанти, при што се настојува да се долови духот на тој период.
\end{abstract}

Клучни зборови: Евреи, Македонија, фолклор, поговорки, приказни.

По големата миграција на Сефардите (група еврејско население, која потекнува од Пиринејскиот Полуостров; нивното име произлегува од хебрејското име на Шпанија - Сефарад) од Шпанија во 1492 година и од Португалија во 1498 година и нивното населување на Балканскиот Полуостров, тие со себе го донеле и својот јазик, кој со текот на време се наметнал и станал основен јазик на сите македонски Евреи. Тоа е еврејскошпанскиот јазик или т.н. ладино. Благодарение на својата повисока култура, како и на својата бројност, Сефардите успеале да им го наметнат еврејскошпанскиот јазик на Романиотите (група еврејско население, која била населена на Балканскиот Полуостров во периодот на римското владеење) и на Ашкеназите (група еврејско население, која се населила на Балканскиот Полуостров од Централна и од Источна Европа; нивното име произлегува од хебрејското име на Германија - Ашкеназ). Она што е карактеристично за ладиното е неговата идентичност со шпанскиот јазик од XV век, со што овој јазик претставува голема придобивка за лингвистичката наука. Доаѓајќи од Пиринејскиот Полуостров, Сефардите со себе донесувале различни дијалекти на шпанскиот јазик, во зависност од тоа дали дошле од: Кастилија, Арагон, Астурија итн. Иако јазикот постепено се унифицирал, сепак, во некои јазични единици на Сефардите се задржале траги од оригиналните дијалекти донесени од Шпанија. 
Бидејќи Евреите биле далеку од Пиринејскиот Полуостров, без никакви понатамошни културни или какви било врски со тие предели, јазикот ладино се развивал во друг правец. Всушност, тој јазик останал сочуван конзервиран, оригинален, онаков како што бил во XV век, со архаичен призвук, но со многу специфичности, кои не се изгубиле. Таквата кардинална појава во светот на лингвистиката досега не е позната. Тоа е, од една страна, одраз на големата културна моќ на Шпанија во тоа време, изразена преку богатствата на нејзиниот јазик, но и на високиот цивилизациски однос и на толеранција кон Евреите во тоа време од страна на сите балкански народи (Колономос, 1995, 226-227). Фамилијарните имиња на балканските Евреи изобилувале со термини од шпанската топонимија. Шпанското влијание било силно и во сефардската кујна. Во големите еврејски центри на Балканскиот Полуостров, синагогите ги носеле имињата на оние шпански градови и области од каде што претходно биле прогонети Евреите.

Хиспанизацијата на градската култура во Солун била долготрајна: иако имало издигнувања и падови во економската состојба и во стандардите на рабинското учење, културниот еврејско-шпански отпечаток се чувствувал сѐ до крајот на Османлиската Империја. Во 1892 година, на 400-тата годишнина од Декретот за протерување на Евреите, донесен од страна на шпанската кралска двојка Фердинанд и Изабела, шпански новинари и политичари го посетиле Солун. Таму тие нашле постојна врска со нивното сопствено минато, оддалечен дел на иберискиот живот, кој со векови бил заборавен во нивната земја. Според зборовите на шпанскиот сенатор, д-р Ангел Пулидо Фернандез, тие биле „Шпанци без родна земја“; но ова не било сосема точно. Нивниот дом бил Солун (Мазовер, 2008, 64).

Евреите во Македонија, својот јазик го нарекувале иудезму, што во превод значи „еврејски“, а не го употребувале вообичаениот термин ладино или жудео-еспањол. Се одело дури дотаму што оној што не зборувал иудезму не бил сметан за Евреин. Од друга страна, Македонците го именувале како еврејски јазик, сметајќи го за оригинално изворен јазик на Евреите. Многу Македонци го научиле јазикот ладино живеејќи, работејќи и делејќи ја судбината со Евреите (Колономос, 1995, 227).

За разлика од ладиното, ивритот не бил говорен јазик на Сефардите, туку се користел само во литургиските служби. Литургиите биле напишани главно на иврит, но делумно и на арамејски. Во секој еврејски дом се чувале Тората (Мојсеевото Петокнижие), старозаветната Библија и Талмудот. Книгата Хагада, која се чита пред празникот Пасха, има делови на иврит и на арамејски, при што паралелно постои и превод на ладино. При читањето прво одел оригиналот, а потоа преводот (Колономос, 1995, 227).

Од друга страна, ладиното бил исклучиво јазик за пишување, претежно литературен, и на него се преведени верските книги и Библијата. Тој се смета за постар јазик од џудезму. Верските текстови на иврит и на арамејски биле преведувани збор по збор на кастилијанско наречје (тогашен официјален дијалект во Шпанија), така што лексиката на ладиното е шпанска и датира од XIII век, а структурата на текстовите е хебрејска, додека текстуално се инфилтрирани одделни зборови од ивритот и од арамејскиот. Текстовите на 
ладино се печателе со хебрејски букви и постоела тенденција тој јазик да ги доближи верските содржини до пошироките маси, а посебно меѓу жените и децата, за да се зацврсти нивниот интерес во синагогите. Истовремено, ладиното овозможувал натамошно полесно совладување на ивритот (Колономос, 1995, 228).

Со текот на времето, во зависност од местото на живеење, се менувал и се збогатувал речникот на ладино, притоа добивајќи нови фонетски, а некогаш и семантички карактеристики. Научните, економските, социјалните и литературните иновации имале битно влијание на речникот и на говорот. Инфилтрацијата на новите зборови, пред сѐ, во голема мера зависела од народите со кои биле во контакт Евреите (словенски, турски, грчки, романски, француски), а најголема експанзија на јазикот се случувала во големите центри (Солун, Истанбул, Белград, Сараево, Софија итн.) (Колономос, 1995, 229). Контактите со други народи, јазици и литератури влијаеле да влезат нови зборови во речникот на јазикот ладино. Најмногу влијание имал францускиот јазик, особено по формирањето на Светската еврејска алијанса (Alliance Israelite Universelle) во 1860 година во Париз. Оваа организација отворила француски училишта во Солун, во Битола и во Скопје. Со основањето на Алијансата, во рамките на Османлиската Империја, ладино сѐ повеќе почнал да се потиснува и да му отстапува место на францускиот јазик (Ortayli, 2002, 129).

Македонските Евреи, сакајќи да се здобијат со пошироко европско образование, се труделе да се доближат до француската култура, која сѐ повеќе се ширела на Балканот. Во Македонија, а посебно во Битола, кон крајот на XIX и на почетокот на XX век, еврејските интелектуалци биле под француско влијание. Францускиот јазик одиграл голема улога во создавањето на еврејско-шпанската литература на Балканот (Колономос, 1996, 123). При преведувањето на литературни дела од познати француски писатели, јазикот на овие преводи содржел и голем број француски зборови, како и француска синтакса, дури и во поголема мера присутна во однос на класичниот шпански јазик. Покрај образованието и литературата, францускиот јазик имал големо влијание врз печатот, научните и литературните публикации (Колономос, 1996, 123). Исто така, зборови од турскиот јазик се чести во еврејскошпанските говори. Ова влијание на турскиот јазик е сочувано во Македонија како културна придобивка од минатото. Евреите, како османлиски поданици, го прифатиле ова културно и јазично влијание.

Македонските Евреи за време на османлискиот период создавале и негувале свој автентичен фолклор. Тој се состоел од народни приказни, песни, раскази, поговорки, досетки и слично, кои биле пренесувани од поколение на поколение. Народните умотворби одиграле голема улога во одржувањето, па дури и во развојот на еврејскошпанските говори. Сефардите, доагајќи од Шпанија, пренесувајќи ги народните умотворби, успеале да ги сочуваат, сѐ до денес, и јазикот и духовноста на народите што живееле во таа земја. Формите во кои е зачуван овој џиновски свет на информации ги сочинуваат: поговорките, приказните, романсите, гатанките и досетките, тажаленките, а во поголемите духовни центри - Библијата, философските и правните расправи, 
како и модифицираните морални и мистични претстави. Чистотата на јазикот и на зачуваната мисла денес ги фасцинира научниците и интелектуалците од широк дијапазон, вклучувајќи ги: етнолозите, лингвистите, философите, уметниците и теолозите од целиот свет (Колономос, 1996, 115). Според Жамила Колономос, во поговорките е опфатен односот спрема трудот на сите категории еврејско население. Притоа, се истакнуваат позитивните и негативните примери, со цел етички да се влијае на младите членови на заедницата. Поговорките се употребувале многу често, во разни пригоди, било во кругот на семејството или меѓу пријатели и соседи. Народните приказни и басни исто така биле проткаени со поговорки, кои имале педагошка смисла. Приказните, исто како и поговорките, се производ на усното предание и ги изразуваат животните проблеми на пошироката човечка заедница. Тие се полни со оптимизам и со верба во човекот, опфаќаат многу позитивни и негативни страни на секојдневниот живот. Приказните претставуваат пригодна форма за спонтано изнесување на недостатоците во меѓучовечките односи, без да предизвикуваат негативни реакции. Голем број приказни имаат мешовита содржина. Од раскажувачот зависело каков ефект ќе предизвика приказната кај слушателите. Имало талентирани раскажувачи, кои од приказните создавале уметнички дела. Тоа биле обично постари луѓе, кои повлечени од активното стопанисување и работа во семејството, имале повеќе време на своите внуци, да им ја пренесуваат мудроста на предците. Некои приказни, децата во играта, ги претворале во скечеви. Приказните обработувале семејни и општествени проблеми: односот меѓу членовите на семејството, соседите, слугата и господарот, владетелот и народот. Многу човечки особини се обработени во различни варијанти, при што се настојува да се долови духот на тој период. Постои и жанрот на хумористични приказни, каде што главниот јунак е измислениот лик Џуха, кој создава хумористични ситуации, сфаќајќи ги буквално или преправајќи се дека така ги сфаќа моменталните состојби, кои можат да имаат двојно значење. Меѓу Сефардите, Џуха се споменува и во некои поговорки (Колономос, 1996, 116). Многу приказни се поврзани со личноста на мудриот цар Соломон и неговата способност и мудрост во решавањето на проблемите во односите меѓу луѓето. Имало и приказни со педагошки карактер, кои биле наменети за децата од предучилишна возраст, со цел тие да научат што е можно повеќе нови зборови и поими. Особено популарни меѓу младата популација биле басните, кои брзо се прифаќале и се пренесувале на следните генерации. Басните се истакнуваат со својот морален карактер и преку нив се осудуваат негативните особини и лошите односи меѓу луѓето. Правдата, мудроста и чесноста секогаш триумфира, додека неработењето, нечесноста, лагата секогаш се изложени на потсмев и казна (Kolonomos, 1978, 35-36). Романсите биле донесени од Шпанија, а Евреите усно ги пренесувале и ги пееле на начин идентичен со оригиналот, но сепак во одделни примери се случувало да бидат уфрлени и нови зборови, па дури и стихови, под влијание на оние средини, каде што живееле. Во романсите насекаде е задржан солунскиот говор, додека другите форми (поговорки, приказни итн.) ги содржат и белезите на јазикот ладино од регионите, каде што биле употребувани, со што од лингвистички аспект се од 
посебен интерес (Колономос, 1996, 116). Во продолжение на овој текст, ќе дадеме неколку примери, кои го потврдуваат значењето на еврејскиот фолклор во формирањето на македонскиот културен мозаик.

\section{Козата и теснотијата}

Еден сиромашен Евреин отишол кај рабинот за да побара совет. Го прашал што да направи, за да се извлече од неподносливата теснотија, во која живеело неговото многубројно семејство.

- Ти нели имаше една коза и ја чуваше во дворот? - праша рабинот.

- Да. Секое утро ја молзам козата и со млекото ги хранам моите деца.

- Козата ке ти помогне да се оттргнеш од теснотијата! Врати се дома, земи ја козата и внеси ја внатре во куќата, заедно со сеното. Потоа ќе видиме што ќе се случи!

Кога изминале неколку дена, рабинот го сретнал Евреинот и го прашал како е ситуацијата со теснотијата во неговата куќа.

- Не прашувајте, рабину! Она што ми се случува, не го доживеал и самиот фараон по Десетте Божји казни! Од таа коза во куќата ми мириса на мрша! Одвреме-навреме козата оди и по мала и голема нужда, а и сеното го расфрлува по целата куќа.

- Така ли! Веднаш да ја изнесеш козата од куќата! Ке ја вратиш на старото место, а по неколку дена ќе дојдеш да ми кажеш што си направил.

По неколку дена, бедниот Евреин отишол кај рабинот. Рабинот го прашал:

- Е, како си сега?

- Фала му на Бога, рабину! Откако ја извадив козата од куќата, заживеавме како луѓе! Бог да те награди, затоа што ми даде толку добар совет! (Москона, 2004, 91).

\section{Седумте бедни години}

Еден прост Евреин сметал дека е голема чест за него да го посетува рабинот и да разговара со него за најразлични работи. Еднаш, тој отишол кај рабинот и најсериозно го прашал:

- Знаете, луѓето велат дека ако, Евреин убие мачка, за тој грев Господ го казнува со седум години беда. Морам да признаам дека веќе некое време се мислам и не можам да си одговорам што ќе се случи по седумте бедни години?

- Ништо особено - му одговорил рабинот. - По седумте години, Евреинот се навикнува со сиромаштијата и тоа му помага да ја поднесе полесно! (Москона, 2004, 90). 


\section{Писмото на Перахија}

Перахија бил добар Евреин, многу побожен, но беден. Имал пет деца и одвај успевал да го прехрани семејството. Неколку дена пред празникот Пасха, тој се чудел како да најде пари за да им купи подароци на сопругата и на децата. По утринската молитва во синагогата, Перахија решил да му напише писмо на Господ, во кое ќе ги каже сите свои желби за претстојниот празник. Го напишал писмото, го потпишал и го фрлил нагоре. Во истиот миг, ветерот го кренал писмото, го носел сѐ повисоко и откако го завртел над градот, го спуштил точно во скутот на султанот, кој седнал да го пие утринското кафе пред шадрванот на својата градина.

Султанот се зачудил, гледајќ́ во својот скут хартија, напишана со непознато писмо и наредил да ги повикаат неговите советници, за да прочитаат што е напишано. Советниците рекле дека писмото е напишано на еврејски јазик, но бидејќи никој од нив не можел да го прочита, решиле да го повикаат главниот рабин. Тој дошол и читајќи го писмото на Перахија, почнал да се смее. Колку повеќе читал, толку повеќе се смеел. Султанот му рекол на главниот рабин:

- Ако е толку смешно, преведи ни го писмото, па и ние да се насмееме!

Главниот рабин го превел писмото, во кое Перахија му се молел на Господа да стори чудо и да му помогне свечено да ја пречека Пасхата. Султанот и неговите советници се насмеале. Но, веднаш потоа султанот рекол:

- Тоа е знак од провидението! Не напразно царот на царевите, владетелот на светот направил тоа писмо да ми падне во скутот. Тоа значи дека Господ ја слушнал молитвата на бедниот Евреин и мене ме избрал да му ја исполнам молбата. Веднаш најдете го Перахија и дајте му двојно повеќе од она што го побарал, една убава куќа за да живее во неа, и илјада жолтици, за да стане трговец. (Москона, 2004, 94-95).

\section{Џуха и семето од камили}

Некој му кажал на Џуха дека постои семе од камили. Мислејќи дека тоа е вистина, Џуха отишол во еден дуќан и побарал да купи од тоа семе. Дуќанџијата, гледајќи со кого си има работа, му продал семе од обична трева. Џуха со ова семе посеал една своја нива и секој ден ја проверувал. По некое време, на ливадата се појавиле траги од кртови. Џуха се израдувал и отишол дома да ја израдува и жена си и почнал да ѝ раскажува дека на ливадата веќе никнуваат малите камили. Жена му на тоа му се смеела, но не можела да го разубеди. По некое време, една вечер допатувале некои трговци со стока, која ја носеле на камили и се задржале покрај ливадата на Џуха. Тука ги растовариле камилите и ги пуштиле да пасат на ливадата на Џуха. Истата ноќ, Џуха дошол да ја провери ливадата. Кога ги видел камилите што паселе, си помислил дека тоа се оние камили што никнале на неговата ливада. Потоа ги донел камилите кон својата куќа и рекол: 
- Жено, нели ти реков дека на ливадата ќе никнат камили? (Ђорђевић, 1939, 17).

\section{Утре ќе се слушне}

Џуха градел куќа, па му биле потребни штици. Знаејќи дека има штици на таванот од куќата на стариот кадија, тој една ноќ се качил на покривот од куќата и почнал да го симнува црепот, со цел да влезе на таванот и да ги украде штиците. Тогаш, некој човек поминал покрај куќата на кадијата и го прашал што прави.

- Свирам, одговорил Џуха.

- Па ништо не се слуша, рекол минувачот.

- Не грижи се, утре ќе се слушне, одговорил Џуха. (Ђорђевић, 1939, 17).

\section{Џуха и новите папучи}

Џуха си купил нови папучи. Кога ги облекол, сите жители во градот што го сретнувале на улица, го прашувале колку ги платил. Џуха донекаде одговарал, па кога му здосадило отишол дома, легнал, се преправил дека е мртов и ѝ рекол на жена си да почне да плаче за него како за мртовец. Жената почнала да плаче и по некое време во куќата се собрале неговите роднини и пријатели да го погребаат. Но во моментот кога сакале да го спуштат во гробот, Џуха скокнал и викнал:

- Моите папучи чинат четири гроша, сега сите знаете. Не треба веќе да ми досадувате со прашања. (Ђорђевић, 1939, 17).

\section{Џуха се бара самиот себе}

Една вечер Џуха си ја соблекол облеката и пред да легне да спие, запишал каде си ги оставил кошулата, капата, панталоните, чевлите и на крајот запишал дека и Џуха е во креветот. Утредента откако станал, го прегледал списокот и ги нашол сите работи што ги запишал, само Џуха не бил во креветот. Тој се зачудил, па почнал да бара под креветот, во долапот и насекаде во куќата, но не можел да го најде. Потоа излегол на улица да праша за него. Одејќи по улицата, тој сретнал еден човек и го прашал дали некаде го видел Џуха. Човекот се изненадил на ова прашање и му одговорил:

- Па ти си Џуха!

- Гледај, те молам, рекол Џуха, јас на тоа не се сетив. (Ђорђевић, 1939, 18).

\section{Магарето на Џуха}

Еден ден, некој човек дошол дома кај Џуха и го замолил да му го позајми магарето, за да го пренесе житото во воденица.

- Би ти го дал, но не е дома. Му го позајмив на друг. 
Откако Џуха го рече тоа, се слушнало рикањето на неговото магаре зад куќата.

- Како си го позајмил, рекол човекот, кога ене ти го магарето зад куќата.

- Ти си чуден човек, одговорил Џуха. Не ми веруваш мене, туку му веруваш на магарето! (Ђорђевић, 1939, 18).

\section{Џуха како лудак}

Му здосадил Џуха на светот со своите глупости, па власта го затворила таму, каде што се затвораат лудаците. Во затворот Џуха побарал да му дадат јадење, но да биде кошер (ритуално еврејско јадење) и му донеле таква храна. Тој ден бил Шабат. По ручекот, Џуха запалил цигара. Стражарот што го чувал, го прашал:

- Како смееш како Евреин да пушиш на Шабат?

- А зарем јас не сум луд, одговорил Џуха, а лудиот човек може сѐ да стори? (Ђорђевић, 1939, 18).

\section{Песни на Сефардите во Битола}

\section{Станувај еврејска младино}

Станувај еврејска младино,

Оти дојде денот

Нашата мајка пак нѐ вика

Да ни даде подеднакво душа.

За неа ќе го жртвуваме

Сиот наш живот,

Да го постигнеме Сион

Дигајќи го нашето знаме.

Да одиме по јасниот пат

По кој одел Херцел,

Да бидеме синови на Сион

И да живееме за нацијата само.

За неа ќе го жртвуваме

Сиот наш живот,

Да го постигнеме Сион

Дигајќи го нашето знаме (Садикарио, 2008, 109).

\section{Ерусалим}

Ерусалим, мајко наша

Многу си трпела,

Си тргала, несреќницо 
Многу си тргала.

Ние ќе пораснеме

И ќе те ослободиме

Ќе те ослободиме

Од проклетата рака (Садикарио, 2008, 111).

\section{Благословен}

Благословен да е Севишниот

Што ни даде ден за простување,

Секоја сабота да е сѐ подобро

За нас и за целиот Израел.

Господ, Севишниот,

Со милоста своја

Да ни испрати многу добрини,

Несреќи и таги да немаме

Ние и целиот Израел (Садикарио, 2008, 127).

Поговорки од Битола:

1. Изгубеното време и светците го жалат.

2. Кој се чува во младоста, има спокојство во староста.

3. Не оплакувај ја сиромаштијата, туку самотијата.

4. Изеден залак нема пријател.

5. Да живеат старите за добро на младите.

6. Гласот на народот е глас од небото.

7. Многу пати оној што им служи на многумина.

8. Со трпение и тревата се претвора во свила.

9. Зборот има четири ќошиња.

10. Нека си оди старата година со клетвите, а да дојде нова со благословите.

11. Вистината испливува горе како зејтинот.

12. Виното во бурето не зборува.

13. На цицијата ни мир, ни одмор.

14. Во недела дава, во понеделник се кае.

15. Пред да го слушнеш прашањето, мисли на одговорот.

16. Отвори ги очите, за друг да не ти ги отвори.

17. Прави ги чекорите колку што ти се нозете.

18. Од многу чалам се нема аир.

19. Слушај ја секогаш и другата страна.

20. Кажи ми што читаш, да ти кажам што мислиш.

21. Џуха умре, лагата остана.

22. Копнежот е појак од смртта. 
23. Трпението е леб и памет.

24. Лошите ноќи поминуваат - лошите зборови не поминуваат.

25. Што не се случува за илјада години, се случува за еден миг.

26. Сакаш да го запознаеш - дај му власт.

27. Големите се расправаат - малите трпат.

28. Не е како што сакаш, туку е како што можеш.

29. Сите вистини не се за кажување.

30. Ако умрел Мојсие, Господ остана (Колономос, Садикарио, 1996, 134-137).

\section{ЛИТЕРАТУРА}

\section{Кирилични изданија}

ЂОРЂЕВИЋ, Т. Р. (1939). Џуха у предању Шпанских Јевреја у Београду, Гласник Етнографског музеја у Београду, књ. 14, 15 - 19;

КОЛОНОМОС, Ж. (1995). Евреите во Македонија и нивниот јазик, Сефардски одгласи: студии и сеќавања за Евреите од Македонија, Скопје: Еврејска заедница на Македонија, Ѓурѓa. 224 - 249;

КОЛОНОМОС, Ж. (1996). Евреите во Македонија и нивниот јазик, Јазиците на почвата на Македонија: прилози за истражувањето на историјата на културата на почвата на Македонија, кн. 3, 111 - 126;

КОЛОНОМОС, Ж. САДИКАРИО, А. (1996). Морфологија на еврејскошпанските говори во Битола и Скопје, Јазищите на почвата на Македонија: прилози за истражувањето на историјата на културата на почвата на Македонија, кн. 3, 127-138;

МАЗОВЕР, М. (2008). Солун, град на духови, христијани, муслимани и Евреи (1430 - 1950). Скопје: Аз-буки;

МОСКОНА, И. (2004). Език, бит и душевност на балканските Евреи. София: Издателски център Шалом.

САДИКАРИО, А. (2008). Корени. Скопје: Еврејска заедница во Република Македонија.

\section{Латинични изданија}

KOLONOMOS, Ž. (1978). Poslovice, izreke i priče sefardskih Jevreja Makedonije. Beograd: Savez jevrejskih opština Jugoslavije.

ORTAYLI, I. (2002). Ottoman Jewry and the Turkish language. The last Ottoman century and beyond: the Jews in Turkey and the Balkans (1808 - 1945). Vol. II, Tel Aviv University, $129-139$. 
Vladimir Janev

\title{
THE SOCIAL-ECONOMIC ASPECTS IN FOLKLORE OF MACEDONIAN JEWS
}

\begin{abstract}
Summary
During the Ottoman period, Macedonian Jews created and cherished their own authentic folklore. It consisted of folk tales, songs, stories, proverbs, riddles, etc., which were conveyed from generation to generation. The proverbs have covered the relation of all categories of the Jewish people towards the labor. Thereby, the positive and negative examples are underlined, in order to ethically influence the young members of the communities. Proverbs were very often used on different occasions, either within the family or among friends and neighbors. Folk tales and fables have also been mixed with proverbs, having a pedagogical sense. The stories, as well as the proverbs, were a product of oral tradition and expressed the life problems of the wider human community. They were full of optimism and faith in man, included positive and negative sides of everyday life. The stories represent a nice form of a spontaneous presentation of the lack in human relations, without causing adverse reactions. The stories deal with family and social problems: the relationship between family members, neighbors, servant and master, the ruler and the people. Many human traits are treated in different ways, and trying to recapture the spirit of that period.
\end{abstract}

